\title{
Public Debt and the Crisis of Development in Nigeria Econometric Investigation
}

\author{
Chris O. Udoka \\ Department of Banking \& Finance \\ University of Calabar, Calabar, Cross River-Nigeria \\ E-mail: udokaco@yahoo.com
}

\author{
Samson Ogege \\ Department of Finance, Faculty of Business Administration \\ University of Lagos, Lagos, Nigeria
}

Tel: 234-080-3669-1036Ｅ-mail: ogegesamson@yahoo.com

Received: July 1, 2012 Accepted: September 13, $2012 \quad$ Published: December 1, 2012 doi:10.5296/ajfa.v4i2.2028 URL: http://dx.doi.org/10.5296/ajfa.v4i2.2028

\begin{abstract}
The study examined the extent of public debt crisis and its consequences on economic development using data from Nigerian economy for the period 1970 to 2010 . It employed the error correction framework and co-integration techniques to test the relationship between per-capita gross domestic product and macroeconomics variables. The test reveals that there is long relationship between dependent and the independent variables. This implies that political instability may reduce rate development and other independent variables are responsible for the underdevelopment of Nigeria. Hence, to avoid the crisis of economic development in Nigeria public debt should be reduce to a minimal level.
\end{abstract}

Keywords: Public debt, Economic Development, Co-integration, Unit Root 


\section{Introduction}

The act of borrowing creates debt. Debt, therefore, refers to the resources of money in use in an organization which is not contributed by its owners and does not in any other way belong to them. It is a liability represented by a financial instrument of other formal equivalent. When a government borrows, the debts is a public debt, Debts are incurred by government through borrowing in the domestic and international markets to finance domestic investment. Therefore, the national debt is seen as all claims against the government held by the private sector of the economy, or by foreigners, whether interest-bearing or not (and including bank held debt and government currency, if any); less any claims held by the government against the private sector and foreigners. In the same vein, public debt burden refers to the economic hardship which the public debt imposes. The hardship may take the form of waste of productive efficiency (misdirection of production) for the economy as a whole or undesirable economic burdens imposed upon particular classes. One concept of burden pertains to the current amount of goods and services which the private sector forgoes in to enable the burden relate to the amount of goods and services forgone by the people during their lifetimes (Anyanwu, 1993). The debt burden in Nigeria has resulted in various distortions in the macro-economy. Essentially, these distortions are structural in nature, and thus affect the level of per capita incomes and are instrumental to the rising poverty in the country. The latter has attracted the attention of various authors and Nigerian economic planners. The various points of view are all agreed that the condition of Africa in general and that of Nigeria in particular have now deteriorated to an economic and political catastrophe (Nzotta, 2004).

Basically, Nigeria began to experience debt problem from the early 1980s when foreign exchange earnings plummeted as a result of the collapse of prices in the international oil market and external loans began to be acquired indiscriminately. The debt crisis, which is the combination of accumulated debt stock and difficulty servicing, has imposed several burdens on the Nigerian economy. This is reflected in the fall in real growth rates, investment rate and export earning since 1980. The debt burden has clearly been a constraining factor on rapid economic recovery growth and development with the debt increasing at an alarming rate. Funds which should have been used for economic development are channeled towards servicing the debt. The constraining effect of the debt burden services is more pronounced as the economy has failed to grow sufficiently to reduce the burden to a sustainable level.

Public debt is an amount of money owned by the government to institutions, government agencies and other bodies' resident in or outside Nigeria. The debt crisis has also generated controversy as to the exact meaning of debt and external debt (Nzotta, 2004). The IMF (1988) defined debt as a liability represented by a financial instrument or other formal equivalent owed to other parties. The World Bank (1988) defined gross external debt as the amount, at any time of disbursed and outstanding contractual liabilities of residents of a country to non-residents to repay principal with or without interest, or to pay interest, with or without principal. Thus, the major objective of this paper is to assess the extent of public debt burden on Nigerian economy from 1970- 2010 and to bring out if there is any relationship between public debt burden and economic growth of the nation. 


\section{Theoretical Framework}

\subsection{Debtcum - Growth Model}

The first stand of thought in the debtcum - growth theory is the substituting school of thought. It considers external debt as a substitute for domestic savings and investment and therefore domestic savings and investment are crowded out as a result (Krugman, 1988; Alesina \& Tabellini, 1990; Tornell \& Velusco 1992). The thinking is that the returns from investing in a country are seen as being subjected to a high marginal tax by creditors and this may discourage domestic and foreign investors. This is the familiar debt overhang theory. It is also argued that foreign savings may be used for consumption rather than for investment. However, studies by Cohen and Sachs (1986) and Cohen (1992) present endogenous growth models where capital accumulation is the driving force for growth.

\subsection{Threshold School of Thought (Debt - Latter Curvethesis)}

The burden of external debt is the concern of threshold school of thought which emphasizes the non-linear relationship between debt and growth (Calvo, 1998). It links debt and growth to problem of capital flight where at high debt levels growth falls. According to the threshold theory, the fall in growth is due to the higher distortionary tax burden on capital required to service the debt. It leads to lower rate of return on capital, lower investment and, hence, lower growth. It maintains that low debt regimes have higher growth rate and lower strand of thought in the debt - growth nexus sees external debt as capital inflow with positive effect on domestic savings and investment and thus on growth which leads to poverty reduction via appropriate targeting of domestic savings and investment (Calvo, 1998). Such foreign capital inflows help to finance a chronic shortfall of domestic savings over investment, the gap in the current account. There should be no problem with the theory as the funds are channeled into production investment which allows the country to grow and generate future export earnings to repay the loan.

\section{Profligacy Theory}

The profligacy thesis attempts to correct the weakness of growth - cum debt theory by focusing on the institutional arrangement under which a loan was contracted. The profligacy thesis, a component of the system stability theory, recognizes that the debt crisis arose from weak institutions and policies that have wasted resources through unbridled official corruption and damaged living standards and development. These policies led to distortions in relative prices and encouraged capital flights - as seen in substantial external liquid funds of private citizens of debtor countries in foreign banks. (Nyong, 2005)

In summary, many factors are identified as responsible for the dissonance between debt and growth in low income countries. These include (1) adverse terms of trade (ii) waste of resources due to policy deficiencies, poor governance, and weak institutions in public sector dominated economies (iii) inadequate debt management reflected in unrestrained borrowing at unfavorable terms. (iv) non-concessional lending and in financing policies motivated in part by the desire of lenders to promote their own exports (Stephens, 1999) (v) political factors such as social strive or tension with devastating economic consequences Nyong, 2005). 


\section{Conceptual Issues on Public Debt}

When the government spends more than it receives which results in the use of some sort of security to cover the deficiency which normally lead external debt as source of fund. The aggregate of securities over timeless redemption is called the national debt (Ajayi, 1991). The fore-going statement points to the fact that government accumulates debt simply by running deficits through borrowing on the distribution of such securities. Also, national debt consists of all securities issued by the federal government and held by the Central Bank of Nigeria, individual and foreigners, government agencies and trust funds, private sector as well as those held by commercial banks.

On the concept of debt burden, Cohen (1992) posited that external debt does not constitute a burden when contracted loans are optimally deployed and the returns on investment is enough to meet maturing obligations, while the surviving of the domestic economy is not undermined. He added that where the reverse is the case, then a debt service burden will emerge.

To properly gauge the gravity of debt burden on Nigerian economy, Anyanwu (1997) argues that neither the overall level of indebtedness nor the aggregate level of debt service payment is an adequate measure of a region or country's problem. He suggested that they should be used in combination with other debt indicators to get a more accurate picture of the situation. According to Nzotta (2004), these other indicators include: the external debt of GDP ratio of debt service to federally collected revenue, the ratio of interest payments to debt stock, and the ratio of outstanding debt stock to GDP. These indicators according to him show the degree of the severity or intensity of external debt burden. Nzotta (2004) described debt service burden as the weight of debt service payment relative to the proportion of national income devoted to servicing of economy. They concluded that debt service problem would arise when maturing obligations cannot be redeemed owing to either bad leadership or insolvency problem.

\section{Nigerian Public Debt}

Various approaches have been adopted towards making public debt sustainable. Under the Structural Adjustment Programme (SAP), Nigeria adopted the following strategies to ameliorate domestic debt: acquisition of domestic debt, restructuring of domestic debt, and servicing of domestic debt. On the external front, the following strategies were employed: embargo on new loans, limit on debt servicing payments (maximum 30\% of export earnings); debt restructuring through refinancing, rescheduling, buyback, issuance of collateralized bonds, and the provision of new money, and debt conversion schemes. In spite of these and international debt reduction strategies such as The Baker Plan (1985), the Paris Club plan (1987), the Africa Development Bank (ADP) plan. The Brady plan (1989), The IMF Facilities (Structural Adjustment Facility, External Fund Facility, the Enlarged Access Policy, the Enhanced Structural Adjustment Facility, and compensatory and contingency financing facility have not change the picture from what it used to be for mostly Africa countries. Despite the World Bank facilities (structural adjusted lending, the reduction facility, the special programme of assistance and the trade investment and policy loan), Toronto and Trinidad terms enhanced Toronto terms, the Housten terms and the Naples term, Nigeria's public debt continuous to grow like an avalanche. (Ajayi, 1991; Ani, 1997; (Anyanwu, 1997). 
Nigeria's External and Domestic Debts:

External Debts

Nigeria's external indebtedness dates back to pre-independence period. However, the quantum of the debt was small until 1978. The debts incurred before 1978 were mainly long-term loans from multilateral and official sources such as the World Bank and the country's major trading partners. The debts were not much of a burden on the economy because the loans were obtained on soft terms. Moreover, the country had abundant revenue receipts from oil, especially during the oil boom of 1973-1976.

The total external debt outstanding as at 31 st December 2004 stood at US\$35.94 billion as against US\$32.92 billion in December 2003, indicating an increase of US\$3.03 billion or 9.20 percent.

As was the case in the year 2003, the increase in the debt stock was largely as a result of the interest component of additional payment arrears that accumulated, and continued depreciation of the US dollar against other currencies in which the debts were denominated. The additional interest of US $\$ 1.54$ billion was made up of contractual interest of US $\$ 1.30$ billion and late/penalty interest of US $\$ 0.233$ billion, but the increase due to the effect of the depreciation of the US dollar was approximately US\$1.49 billion.

A further breakdown of the total debt outstanding showed that the principal balance was US\$30.29 billion; principal arrears amounted to US\$1.94 billion, interest arrears and late interest were US\$3.36 billion and US\$0.357 billion respectively. The increase in the external debt stock was due primarily to arrears that were incurred as a result of non-servicing of the non-ODA (non-official development assistance) bilateral debt: arrears on this debt accounted for 96.6 percent of total arrears.

\section{Debt Servicing}

The total external debt service payment for the year 2004 was US $\$ 1.75$ billion compared to US $\$ 1.81$ billion in 2003, reflecting a decrease of US\$0.054 billion or 3.01 percent. The external debt service payments of US\$1.75 billion comprised of principal repayments of US $\$ 1.17$ billion, and interest payments and commitment charges of US\$0.589 billion. It is important to note that the US\$1.75 billion debt service paid in 2004 is actually well below the debt service due for the year of US\$2.99 billion. This arises because Nigeria has not fully serviced its Paris Club debts, as an amount of US\$2.23 billion was due but only US $\$ 0.99$ billion was paid. The shortfall transforms into arrears and attracts severe penalty interest. This very process has contributed to the explosion in Nigeria's external debt stock over the years. (DMO, 2010)

\section{Domestic Debts}

Domestic debt is defined as debt denominated in local currency. The management of domestic debt in Nigeria has hitherto been conducted by the Central Bank of Nigeria (CBN) through the issuance of government debt instruments, which consisted of: 
- Nigerian Treasury Bills

- Nigerian Treasury Certificates

- Federal Government Development Stocks

- Treasury Bonds

- Ways and Means Advances.

It is important to note that the above given position does not include contractor debts and supplier credit owed by the government, which are estimated at about N650 billion. Neither does it include contingent liabilities, which are loans guaranteed by the Federal Government, nor inter-agency debt.

In the year 2004, the DMO made plans to build on the success of the 1st FGN Bonds floatation that were first issued in 2003. The DMO embarked on the arrangements to commence the issuance of bonds on a regular basis in small tranches that the market could accommodate.

The DMO commenced the smoothening and restructuring of the Treasury Bills in 2004. The restructuring entailed extending the maturities of the existing Treasury Bills by issuing tenors of 6, 12, 24, and 36 months, to refinance part of the existing 91-day Treasury Bills

\section{Methodology}

Based on the objective of the study and on the basis of what has been discussed in the theoretical framework, the following model will be specified. The paper attempts to assess the impact of public debt and the crisis of development in Nigeria .The knowledge of economic theory suggests that a critical factor in assessment of economic development is the Per-Capita Gross Domestic Product (PCGDP). However, our model shall contain Gross Domestic Product as the dependent variable, while

Foreign reserve, debt stock, investment, debt service payment, total trade/ GDP ratio and political stability are the explanatory variables.

Therefore, this applies to the error correction method to a regression model based on the traditional relationship between public debt and economic development distilled from the literature. The idea is to subject the variables to stationarity test and subsequently remove the non- stationary trends by differencing before regressing. This removes the possibility of the so-called spurious regression. The analysis here is primarily based on Engle and Granger (1987). The idea is to determine the order of integration of the variables, that is, we test whether they are stationary in their levels or whether they have to be differenced once or more before they become stationary. Testing for unit roots is carried out by using an Augmented Dickey-Fuller (ADF) test.

$$
\text { GDP }=\text { F( FR, DSK, FRINV,DSP, OPEN, POL) }
$$

The above model is hereby written in log - linear form as: 
(L) GDP $=b_{o}+b_{1} F R(L)+b_{2} \operatorname{DSK}(L)+b_{3} \operatorname{FRINV}(L)+b_{4} \operatorname{DSP}(L)+b_{5}$ OPEN(L) $+b_{6}$ POL $(L)+$ $\mu_{\mathrm{t}}$

Where:

$\mathrm{FR}=$ foreign reserve

$\mathrm{DSK}=$ total debt stock

FRINV $=$ Foreign investment

$\mathrm{DSP}=$ Debt service payment

OPEN = OPENNESS OF THE ECONOMY (TOTAL TRADE /GDP RATIO)

POL $=$ POLITICAL INSTABILITY DUMMY $=1$ MILITARY

REGIME AND TURBULENT YEARS, 0 OTHERWISE

$\mu=$ Scholastic Error sign.

"The Data Analysis technique consists of an approach designed to capture the long-run relationship between the dependent and independent variables, but avoiding spurious influences. These are the co-integration and error correction techniques which have received prominent attention in literature (see Adam, 1992, Engle and Granger, 1987, and Thomas 1993).

The aim of the new framework was to ascertain the time characteristics of data, overcome the problems of spurious correlation often associated with none - stationary time series data, and generated long-run variable relationship simultaneously. Within this dispensation, an important starting point for research is an assessment of the degree of integration of the relevant variables and to check whether they are co-integrated or not. It should be noted that an important issue in econometrics is the need to integrate short-run dynamics with long-run equilibrium. The analysis of short-run dynamics is often done by first eliminating trends in the variables, usually by differencing. The theory of co-integration development in Granger (1981) and elaborated in Engle and Granger (1987) addressed this issue of integrating short-run dynamics with long-run equilibrium.

Similarly, it is important to note that the usual starting point of ECM modeling is to assess the order of integration of both the dependent and independent variables in the model. The order of integration ascertains the number of time a variable will be differentiated to arrive at stationary. Dickey-fuller (DF), Augmented Dickey-Fuller (ADF) and Sargan - Rhargava Durban-Watson (SRDW) are the widely used test for stationary for both individual time series and residual from OLS regressions. Co-integration is based on the properties of the residuals from regression analysis when the series are individually non-stationary.

The original co integration regression is specified as follows:

$$
\mathrm{A}_{\mathrm{t}}=\alpha_{0}+\alpha_{1} \beta_{t}+\ell_{t}
$$


Where A represents the dependent variables, $\beta$ stands for the independent variable, and e is the random error term. $\alpha_{0}$ and $\alpha_{1}$ are intercept and slope coefficients respectively. To include the possibility of bi-directional causality, the reverse specification of equation 1 is considered.

To provide a more defensive answer to the non-stationarity in each time series, the Dickey-Fuller (1979) regression is estimated as follows for a unit root:

$$
\Delta \mathrm{e}_{\mathrm{t}}=-\lambda \mathrm{e}_{\mathrm{t}-1}+\mathrm{w}_{\mathrm{t}}
$$

If $\mathrm{X}$ Equals zero e is non-stationary. As a result, $\mathrm{A}$ and $\mathrm{B}$ are not co-integrated. In other words, if $\mathrm{X}$ is significantly different from zero $\mathrm{A}$ and $\mathrm{B}$ is found integrated individually.

Given the inherent weakness of the root test to distinguish between the null and the alternative hypothesis, it is desirable that the Augmented Dickey-Fuller (ADF) (1981) test be applied. The desirability is warranted because it corrects for any serial correlation by incorporating lagged changes of the residuals. To be co-integrated, both A and B must have the same order of integration (Eagle and Granger, 1987 ).

The ADF regression is specified as follows:

$$
\Delta \ell_{t}=\beta_{o} \ell_{t-1}+\sum_{j=i}^{m} \beta_{j} \Delta \ell_{t-1}+\mu_{t}
$$

Where $\Delta$ is the first difference operator and $\mu_{\mathrm{t}}$ is the plew random error term. $\mathrm{M}$ is the optimum number of lags needed to obtain "white noise". This is approximated when the DW value approaches 2.0 numerically. The null hypothesis of non co-integration is rejected, if the estimated ADF statistics is found to be larger than its critical value at 1 or 5 or 10 per cent level of significance.

if $A_{t}$ and $B_{t}$ are found to be co-integrated, then there must exist an associated error-correlation Model (ECM), according to Engle and Granger (1987). The usual ECM may take the following form:

$$
\Delta \mathrm{G}_{\mathrm{t}}=\sigma_{\mathrm{o}} \mathrm{e}_{\mathrm{t}-1}+\sum_{j=1}^{T} \sigma_{1} \Delta \mathrm{A}_{\mathrm{t}-\mathrm{j}}+\sum_{j=1}^{T} \theta_{j} \Delta \mathrm{B}_{\mathrm{t}-\mathrm{j}}+\mathrm{V}_{\mathrm{t}}
$$

Where $\Delta$ denotes the difference operator $\mathrm{e}_{\mathrm{t}-1}$ is the error correction term, $\mathrm{T}$ is the number of lags necessary to obtain white noise and $\mathrm{V}_{\mathrm{t}}$ is another random disturbance term. If $\sigma_{\mathrm{o}} \mathrm{e}_{\mathrm{t}-1}$ is significantly different from zero, then $\mathrm{A}$ and $\mathrm{B}$ have long-Run relationship. The error-correction term $\left(\mathrm{e}_{\mathrm{t}-\mathrm{I}}\right)$ depicts the extent of disequilibrium between $\mathrm{A}$ and $\mathrm{B}$ The ECM, reveals further that the change in $A_{t}$ not only depends on lagged changes in $B_{t}$, but also on its own lagged changes. It is appealing due to its ability to induce flexibility by combining the 
short-run and long-run dynamics in a unified system. Also, the estimates of the parameters of the ECM are generally consistent and efficient (Granger, 1969).

Table 1. Stationary Test

\begin{tabular}{|l|c|c|}
\hline Variables & ADF Test & Order of Integration \\
\hline Log GDP & $0.04925(-29969)$ & $1(1)$ \\
\hline Log FR & $-3.7333(-3.0114)$ & $1(0)$ \\
\hline Log FRINV & $-3.6876(-2.9798)$ & $1(0)$ \\
\hline Log DSP & $-2.0299(-2.9798)$ & $1(1)$ \\
\hline A Log OPEN & $-3.5063(-2.9850)$ & $1(0)$ \\
\hline Log OPEN & $-4.2833(-2.9798)$ & $1(0)$ \\
\hline Log INV & $-3.3697(-2.9798)$ & $1(0)$ \\
\hline Log INFL & $-1.3068(-2.9969)$ & $1(1)$ \\
\hline A Log INFL & $-40706(-3.0038)$ & $1(0)$ \\
\hline Log OPEN & $0.8224(-2.9798)$ & $1(1)$ \\
\hline A Log OPEN & $-4.1436(-2.9850)$ & $1(0)$ \\
\hline Log MS & $-1.1022(-2.9798)$ & $1(1)$ \\
\hline A Log MS & $-3.0994(-2.9850)$ & $1(0)$ \\
\hline
\end{tabular}

Source: Authors' computation (2012)

Table 2. Johansen Co-integration Test Results

\begin{tabular}{|c|c|c|c|c|}
\hline $\begin{array}{l}\text { Sample: } 1970 \text { - } 2010 \\
\text { Series: Log GDP, Log FR, Log DSK, Log DSP, Log OPEN, }\end{array}$ \\
\hline Eigen value & Likelihood Ratio & $5 \%$ & $1 \%$ & Hypothesized \\
\hline & & Critical & Critical & No. of CE(s) \\
\hline & & Value & Value & \\
\hline 0.84 & 114.3228 & 94.15 & 103.18 & None** \\
\hline
\end{tabular}

Note:* $\left.{ }^{* *}\right)$ (denotes rejection of the hypothesis at $5 \%$ (1\%) significance level.

L. R. test indicates 2 co-integration equation(s) at 5\% significance level.

Lags interval: 1 to 1

Source: Authors' computation (2012) 
Table 3. Long-run Capital Adequacy Determinants Model Estimates

\begin{tabular}{|l|c|c|}
\hline \multicolumn{3}{|c|}{$\begin{array}{c}\text { Modeling Log (PCGDP) by OLS } \\
\text { Sample: 1970 - 2010 }\end{array}$} \\
\hline Variable & Co-efficient & t-value \\
\hline Log PCGDP & 0.6772 & $3.4397 * * *$ \\
Log FR & -0.1325 & -1.2558 \\
Log OPEN & 0.2896 & 5.1303 \\
Log DSP & 0.6427 & $30.9551 * * *$ \\
\hline
\end{tabular}

Notes: Adj. $\mathrm{R}^{2}=0.72 \quad \mathrm{~F}=21.327 \quad \mathrm{a}=0.45 \quad \mathrm{R}^{2}=0.75 \quad$ Prob(F--Statistic) $=0.00000$

$\mathrm{Dw}=1.87 \quad$ Schwarz information criterion 1.561

* Significant at $1 \%$ Level

** Significant at 5\% Level

*** Significant at $10 \%$ Level

$\mathrm{a}=\mathrm{S}$. E. of regression

Source: Authors' computation (2012)

Table 4. Short-run over — parameterized Capital Adequacy Determinants Model

\begin{tabular}{|c|c|c|}
\hline Model & Log (PCGDP) by OLS & Sample: $1970-2010$ \\
\hline Variables & Co-efficient & t-value \\
\hline Constant & 1.2840 & 2.6798 \\
\hline$\Delta \log C A D(-1)$ & -0.5866 & $-3.9531 * * *$ \\
\hline$\Delta \operatorname{LogFR}$ & -0.2160 & -0.8619 \\
\hline$\Delta \operatorname{LogFR}(-1)$ & 0.1434 & 0.7085 \\
\hline$\Delta \operatorname{LogDSK}$ & 0.9177 & $3.5113 * * *$ \\
\hline$\Delta \log \operatorname{DSK}(-1)$ & 0.5939 & 0.7142 \\
\hline$\Delta$ FRINV & -0.0096 & -0.8264 \\
\hline$\Delta$ FRINV(-1) & -0.0175 & -1.5620 \\
\hline$\Delta \operatorname{LogDSP}$ & -0.3253 & -1.0929 \\
\hline$\Delta \operatorname{LogDSP}(-1)$ & 0.6758 & 1.8781 \\
\hline$\Delta$ Log OPEN & -0.1542 & -0.5330 \\
\hline$\Delta \log$ OPEN $(-1)$ & -0.1861 & -0.6258 \\
\hline POL & -0.0933 & -0.5043 \\
\hline $\operatorname{ECM}(-1)$ & -0.5414 & $2.4385^{* *}$ \\
\hline
\end{tabular}

Notes: $\mathrm{R}^{2}=0.93 \quad \mathrm{~F}=10.01 \quad \mathrm{a}=0.200 \quad$ Adj $\mathrm{R}^{2}=0.83 \quad$ Prob $(\mathrm{F}-$ Statistic $)=0.007975$ $\mathrm{DW}=136 \quad$ Schwarz information criterion $=0.705$

Source: Authors' computation (2012) 
Table 5. Short-run Parsimonious Model Estimates

\begin{tabular}{|l|c|c|}
\hline \multicolumn{2}{|c|}{ Modeling } \\
Sample: 1970 - 2010 \\
\hline Variables & Co-efficient & t-value \\
\hline Constant & 1.648 & 3.9047 \\
Log PCGDP (-1) & -0.6818 & $-3.816^{* * *}$ \\
Log FR & 0.0265 & 0.357 \\
Log DSK & 0.8227 & $3.1236^{* * *}$ \\
Log FRINV (-1) & -0.0193 & $-5.0554^{* * *}$ \\
Log DSP & -0.1811 & -0.5548 \\
Log OPEN (-1) & -0.2630 & $-1.3896^{* *}$ \\
POL & -0.2672 & -1.4278 \\
ECM (-1) & 0.44711 & $2.2388^{* *}$ \\
& -1.2350 & $-4.7628^{* * *}$ \\
& 0.3498 & $3.5534^{* * *}$ \\
& -10.5611 & $-2.9942^{* * *}$ \\
\hline
\end{tabular}

Notes: $\quad \mathrm{R}^{2}=0.89 \quad \mathrm{~F}=10.09 \quad \mathrm{a}=0.24$

*** Significant at 1\%Adj $\mathrm{R}^{2}: 0.80 \quad$ Prob (F-statistic) $=0.000266$

** Significant at 5\% DW=2.11 Schwarz information criterion $=1.10$

* Significant at $10 \%$

Source: Authors' computation ( 2012)

\section{Empirical Results and Findings}

It was discovered through this study that, there were long run relationship between total debt stock, debt service payment and Political Instability. Also, all the variables employed in this study were all stationary at their first difference except foreign investment that is stationary at its level. There are some major findings that this study has revealed.

From the result of the study, one could see that total debt stock has a positive relationship with per-capita gross domestic product in Nigeria. Its high coefficient and very strong level of significance even at one percent suggests that increase in total debt stock leads to an increase in per-capita gross domestic product. Also even other independent variables are relevant. Lastly, the political dummy used as proxy for political instability was appropriately signed indicating that intermittent coup d'etat and incessant political upheaval may serve to scare away potential foreign investors thereby, reducing per-capital gross domestic product and increasing our debt profile in Nigeria.

\section{Conclusions}




\section{Al Macrothink}

Asian Journal of Finance \& Accounting

ISSN 1946-052X

2012, Vol. 4, No. 2

The primary objective of the study was to analyze the effect of debt burden (both internal and external) on the growth of Nigerian economy. Nigeria has relied much on public debt to finance its development projects in the past two decades ago with public debts which put its debt profile so high. From the analysis above it was reviewed that PCGDP which was used to represent the Nigerian economic development as well as the dependent variable. Meaning that rate of development of the Nigerian economy relies strongly on the contribution of the explanatory variables. Thus, before the debt write-off by the Paris-club and London club the result shows that the impact on Nigeria economy was much compared to present time. Though, the exit from the Paris club and London club actually reduced Nigeria's external debt, whereas the domestic debt and the effect created by the huge debt before the debt write-off still have lag effect on the economy. Therefore, based on the above findings we recommended that Nigeria should not borrow now either internally or externally. More so with the conformable position of our external reserve we believe that the Nigerian economy will certainly improve tremendously

\section{References}

Adam, C. S. (1992). Recent Developments in Econometric Methods: An Application to the Demand for Money in Kenya. Economic Research Consortium Special Paper 15.

Ajayi, S. I. (1991). Macroeconomic Approach to External Debt: The case of Nigeria. AERC Research paper eight, Nairobi, December. http://idl-bnc.idrc.ca/dspace/bitstream/10625/11779/1/90214.pdf

Alesina, A., \& Tabellini, G.(1990). External debt, capital flight and political risk.

Ani A. (1997). Details of budget 1997: Text of the 1997 Federal Budget Breakdown Presented in Abuja,Monday, January 20, 1997 by minister of Finance, chief Anthony Ani, Daily Champion, January 21

Anyanwu J. C. (1997). Monetary Economics: Theory, Policy and Institutions. Hybrid Publishers LTD, Onitsha.

Calvo, G. (1989). Growth, debt and economic transformation: The Capital Flight problem;in Coricelli, F. and Hahn, F. (eds), New Theories in growth and development, st. martins press, pp. $847-868$

Central Bank of Nigeria. Annual Report and Statement of Accounts various issues

Cohen, D., \& Sachs, J. (1986). Growth and external debt under risk of debt repudiation. European Economic Review, 30, 529-550.

Cohen, D. (1992). Large external debt and (show) domestic growth: A Theoretical analysis. Journal of Economic Dynamics and control, 19, 1144-1163.

Dickey, O.A., \& Fuller W. A. (1981). Likelihood Ratio Statistic for Auto-Regression Times Series with a Unit Root. Econometrical, 4, 1057-1071.

Engle, R.F., \& Granger, C. W. J. (1987). Co-integration and Error Correction. 


\section{Macrothink}

Asian Journal of Finance \& Accounting ISSN 1946-052X

Granger, C. W. J. (1969). Investigating Causal Relations by Econometric Models and Cross-Spectral Methods. Econometrica, 37, 424-438. http://dx.doi.org/10.2307/1912791

Krugman, P. (1988). Financing vs forgiving a debt overhang. Journal of development Economics, 22, 253-268. http://dx.doi.org/10.1016/0304-3878(88)90044-2

Nyong, M. O. (2005). International Economics: theory, policy and application. Calabar, Wusen publishers.

Nzotta, S. M. (2004). Money, banking and finance. Owerri;Hudson-Jude Nigeria Publishers.

Stephens, M. (1999). The Changing Role of Export Credit Agencies (Wasshington DC, IMF)

Thomas, R. C. (1993). Introductory Econometrics, theory and Applications. Second Edition (Eds). Robert Mil Michael T. Summer and George Zia. Longman Economic Series. London and New York.

Tornell, A., \& Velasco, A. (1992). The tragedy of the commons and economic growth; Why does capital flow from poor to rich countries. Journal of Political Economy, 100, 1208-1231. http://dx.doi.org/10.1086/261858 